\title{
Microwave assisted synthesis and antimicrobial evaluation of symmetrical I,2-Phenylenediamine Schiff's base derivatives
}

\begin{abstract}
Seven Schiff bases were prepared by reacting phenylenediamine with different aromatic aldehyde derivatives. The structures of these compounds were confirmed through different spectroscopic techniques including FT-IR, ${ }^{1} \mathrm{H}-\mathrm{NMR}$ spectroscopy. The synthesised compounds were evaluated in vitro for their antimicrobial activity against Staphylococcus aureus (ATCC 29213), Escherichia coli (ATCC 25922) and Candida albicans (ATCC 10231) using agar diffusion method. The antibacterial and antifungal activities of the synthesized compounds were compared with ciprofloxacin and ketoconazole respectively as the standard compounds. Compound $\boldsymbol{S} \boldsymbol{w} 4$ showed excellent activity against Staphylococcus aureus, Escherichia coli and Candida albicans, while compound $\boldsymbol{S w} 3$ showed moderate activity agonist Candida albicans only. The obtained results could be considered as a promising and potential antibacterial and antifungal agent; further modification can be performed on the structure of the compound for a improved drug candidate in the future.
\end{abstract}

Volume 6 Issue 5 - 2018

\author{
Sofian S Mohamed,' Inass A Al sadawi,' \\ Mohamed A Gbaj, ${ }^{2}$ Sami G Alsabri,' Nahd M \\ Elmaki, ${ }^{3}$ Salah M Bensaber,' Anton Hermann, ${ }^{4}$ \\ Abdul M Gbaj' \\ 'Department of Medicinal Chemistry, Faculty of Pharmacy, \\ University of Tripoli, Libya \\ ${ }^{2}$ Department of Chemical Engineering, Faculty of Engineering, \\ University of Tripoli, Libya \\ ${ }^{3}$ Department of Pharmacy and Medical Devices, Ministry of \\ Health, Libya \\ ${ }^{4}$ Department of Biosciences, University of Salzburg, Austria
}

\begin{abstract}
Correspondence: Abdul M Gbaj, Ph.D.,Associate Professor of Genetics and Biochemistry, University of Tripoli, Libya, Tel +218913556785, Email abdulgbaj I@hotmail.com
\end{abstract}

Received: August 17,2018 | Published: September 06, 2018

\section{Introduction}

Schiff's bases (imine) are compounds that are containing azomethine group $[-\mathrm{HC}=\mathrm{N}-]$ in their structure, formed by condensation of an dynamic carbonyl compound with a primary amine. ${ }^{1,2}$ Schiff bases have also been shown to show a big range of biological activities, including anti-inflammatory, antibacterial, antifungal, antiproliferative, antimalarial, antiviral, and antipyretic pharmacological activities. ${ }^{3-7}$ Azomethine or imine groups can be found in a variety of natural e.g. ancistrocladidine (antimalarial), natural-derived e.g. chitosan (antifungal), and non-natural compounds e.g. N-(Salicylidene)-2-hydroxyaniline (antibacterial). The imine group in such compounds has been shown to be significant to their biological activities. ${ }^{8-10}$ Furthermore, the metal complexes of Schiff compounds have been of main attention for a lengthy time due to their capability to join oxygen to redox systems ${ }^{11}$ that are oxidizing DNA. ${ }^{12}$ They showed noteworthy antimicrobial activity owing to the free radical scavenging capability of their metal composites. Many research groups have been concerned in the chemical synthesis and biological testing of Schiff bases. It has been reported that the synthesized series of 2,4-dichloro-5-fluorophenyl from triazole Schiff bases through aminomethylation with secondary/substituted primary amines and formaldehyde exhibited promising antibacterial and antifungal activity and they found that the aldehyde Schiff base $\mathrm{N}$-aryl thiosemicarbazones had capability as anti-MRSA power and being efficient at nearly half the concentration of the vancomycin. ${ }^{13}$

In addition, Anush et al., ${ }^{14}$ has synthesized a new series of Schiff base by the reaction of Chitosan with different substituted pyrazole4-carbaldehydes in acidic condition. They also compare Schiff bases and chitosan for their antimicrobial ability against many bacteria such as Bacillus subtilis, Staphylococcus aureus, Escherichia coli, Klebsiella pneumonia, and on fungi such as Candida albicans. Their results indicated a higher antibacterial and antifungal inhibitory effect of these Schiff bases compared to Chitosan and the degree of inhibition diverse with the character of substitution. ${ }^{14}$ Dhayabaran and Prakash have synthesized a novel Schiff base, (S,Z)-4-(methylthio)2-((3-oxo-2,3-dihydro-1H-inden-1-ylidene)amino)butanoic acid (L) and four $\mathrm{M}(\mathrm{II})$ complexes (where $\mathrm{M}=\mathrm{Cu}, \mathrm{Co}, \mathrm{Zn}$ and $\mathrm{Ni}$ ) and they found these complexes display superior antioxidant activities against DPPH [2,2-diphenyl-1-picrylhydrazyl] radical and have good in vitro antifungal and antibacterial activities. ${ }^{15}$ In vision of the extensive attention in the biological activity and outline of Schiff bases derived from aldehydes due to their pharmacological interest, we illustrated here the synthesis and description of seven Schiff bases derived from phenylenediamine with different aromatic aldehyde which, several of them are to the best of our information, have not before been depicted in the literature. The antimicrobial activity of the synthesized compounds was evaluated. MAOS (microwave assisted organic synthesis) has emerged as a innovative lead in organic synthesis. The MAOS technique presents efficient, easy, economic, clean and fast for the synthesis of a huge number of organic molecules. There are many advantages of this technology include extremely accelerated rate of the chemical reaction, improvement in the quality and yield of the product. In addition, the technique is assumed as an significant application in the direction of green chemistry, since this technique is friendly to the environment. ${ }^{16,17}$

\section{Material and methods}

\section{Chemistry}

The entire the chemicals and solvents used in the chemical synthesis of Schiff's base were highest quality and were used without further purification. All the chemical were purchased from Fluka analytical company, Sigma-Aldrich and, UK. Synthesis of compounds was carried out in microwave oven start $\mathrm{E}$ which was purchased from Milestone Company, Italy. TLC (Thin layer chromatographic) 
analyses were done on pre-coated aluminum plates (silica gel 60778, Fluka analytical). The visualization of TLC spots was performed under UV light. Melting points were determined in open capillary tubes on an Electro thermal SMP30 melting point apparatus (Stuart, UK). The ${ }^{1} \mathrm{H}-\mathrm{NMR}$ spectra were measured on ultra shield Bruker 400 spectrometer using TMS as an internal standard. Finally, the infra-red spectra were measured in Varian FT-IR spectrophotometer 660.

General procedure for synthesis of Schiff base (SwISw7)

The Schiff's base was prepared by reaction of one mole of phenylenediamine and two moles of substituted aromatic aldehydes (Table 1). All reactants were mixed together, and then minimum amount of ethanol was added. This mixture was subjected to microwave irradiation at 350 watt for $2-3$ minutes at $60^{\circ} \mathrm{C}$. The development of reaction was watched on TLC. After complete of the reaction, the mixture was left for cooling and then solid product (crude) was gathered by filtration and washed many times with alcohol (ethanol) and then dried utilizing vacuum. The obtained product was redissolved in ethanol for recrystallization and after that dried to give a clean pure product (Scheme 1).

Table I Chemical structures of aromatic aldehydes used in chemical synthesis
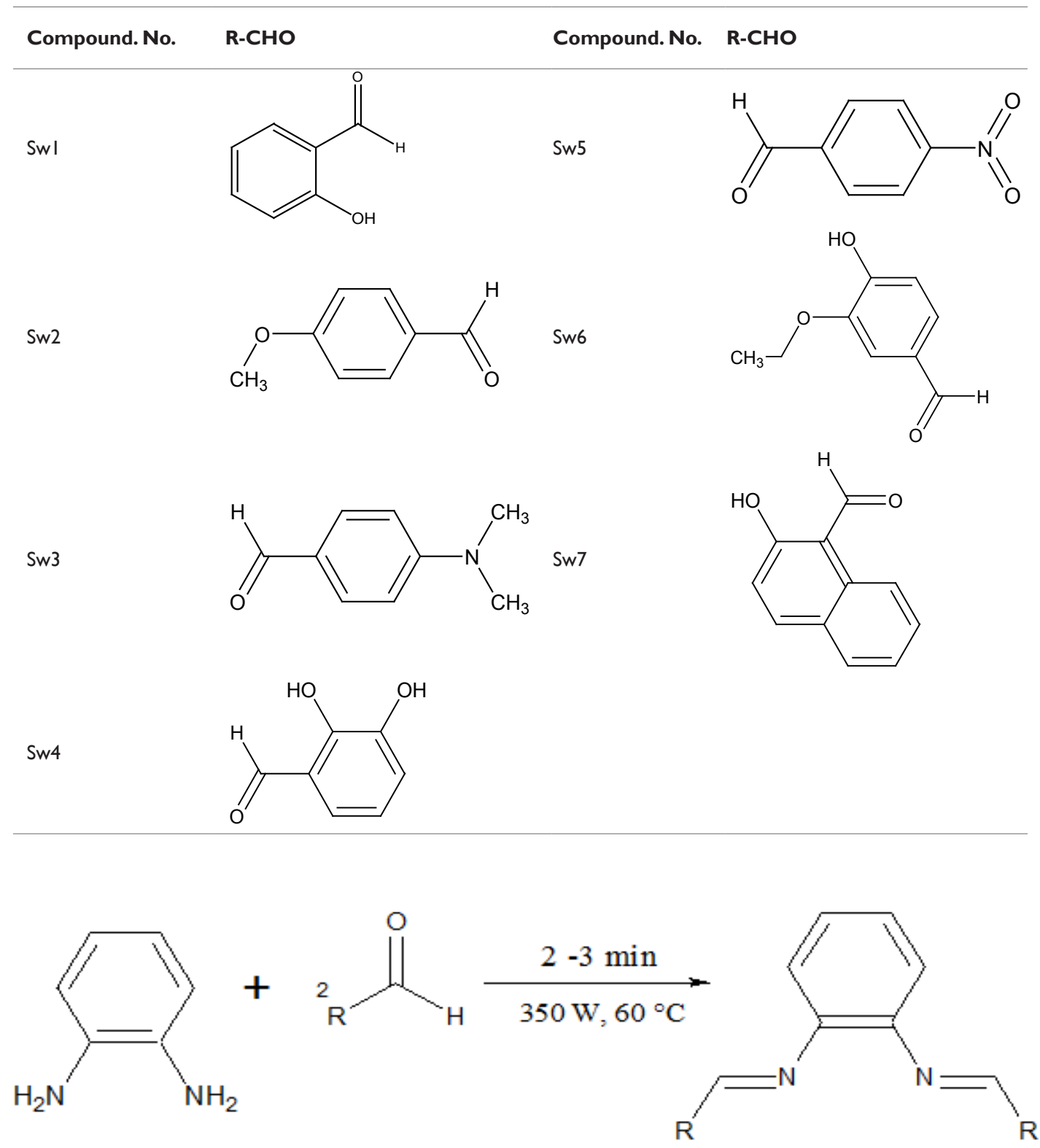

Scheme I General scheme for the synthesis of Schiff base compounds Sw I- Sw7. 


\section{Biology}

The antimicrobial activity of all the synthesized compounds $(\boldsymbol{S} \boldsymbol{w} \mathbf{1 - S w} 7)$ was tested against variety of microorganisms. The microorganisms were purchased from the American type of cell culture collection (ATCC), including Escherichia coli (ATCC 25922), Staphylococcus aureus (ATCC 29213), and Candida albicans (ATCC 10231) at the concentration level of five micromolar by Agar diffusion method. ${ }^{18}$ Ketoconazole and ciprofloxacin were used as reference compounds for antifungal and antibacterial activities and they were obtained from Liofilchem, Italy. The antimicrobial results were documented in the form of inhibition zones [diameter, $\mathrm{mm}$ ] and activity values are shown in Table 3 . Minimum inhibitory concentration (MIC) of any compound is defined as the lowest concentration which totally inhibits visible growth (turbidity on liquid media). MIC values were determined by testing performed according to the literature. ${ }^{18}$ All determinations were done in triplicate and found the same result.

\section{Result and discussion}

\section{Chemistry}

The Schiffs bases $(\boldsymbol{S} \boldsymbol{w} \mathbf{1}-\boldsymbol{S} \boldsymbol{w} 7)$ were prepared by condensation of phenylenediamine with aromatic aldehyde at ratio $(1: 2)$ and exposure to irradition of microwave. All the synthesized compounds were purified by successive recrystallization using ethanol, and the purity was checked by performing TLC. A percentage yield of synthetic compounds was excellent. The physical properties of synthesized compounds are described in Table 2. The Infrared spectra of the synthesized compounds confirmed by the existence of stretching of $\mathrm{C}=\mathrm{N}$ bands at a range of $1500-1690 \mathrm{~cm}^{-1}$ and the nonexistence of carbonyl $(\mathrm{C}=\mathrm{O})$ at $1700 \mathrm{~cm}^{-1}$ whereas $\mathrm{NH}$ is vanished or hidden underneath the broad band's at $3450-3300 \mathrm{~cm}^{-1}$ in Schiff's base. The ${ }^{1} \mathrm{H}-\mathrm{NMR}$ spectra of the synthesized compounds were recorded in DMSO- $\mathrm{d}_{6}$. The chemical shifts $(\delta)$, articulated in ppm downfield form TMS (tetamethylsilane) and are shown in Table 2.

Table2 The physical properties and he spectra data of the synthesized compounds

\begin{tabular}{|c|c|c|c|c|}
\hline $\begin{array}{l}\text { Comp. } \\
\text { NO }\end{array}$ & M.Wt & $\begin{array}{l}\text { M.P } \\
\left({ }^{\circ} \mathrm{C}\right)\end{array}$ & $\begin{array}{l}\text { YILED } \\
(\%)\end{array}$ & FT-IR $\left(\mathrm{cm}^{-1}\right)$ \&'H- NMR ( ppm) \\
\hline SWI & 344.40 & 157 & 95 & $\begin{array}{l}\text { FT-IR }\left(\mathrm{cm}^{-1}\right): \text { I } 609(\mathrm{HC}=\mathrm{N}), \mathrm{I} 5605(\mathrm{C}=\mathrm{C} \text { aromatic }), \mathrm{I} 36 \mathrm{I}(\mathrm{C}-\mathrm{N}), \mathrm{I} 275(\mathrm{C}-\mathrm{O} \text { phenolic). } \\
\left.\text { 'H-NMR } \delta \text { ppm }\left(400 \mathrm{MHz}, \mathrm{DMSO}-\mathrm{d}_{6}\right): \text { I3(s, } 2 \mathrm{H}, \mathrm{OH}\right), 8.92(\mathrm{~s}, 2 \mathrm{H}, \mathrm{CH}=\mathrm{N}), 7.70-6.95(\mathrm{~m} \text {, } \\
\text { I2H, C-H aromatic). }\end{array}$ \\
\hline SW2 & 372.45 & 195 & 93 & 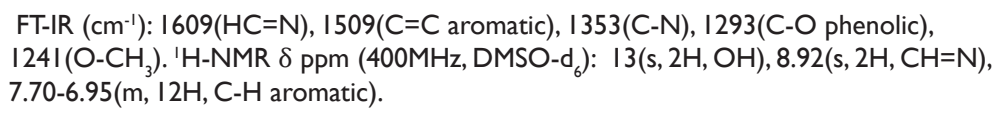 \\
\hline SW3 & 374.52 & 332 & 87 & 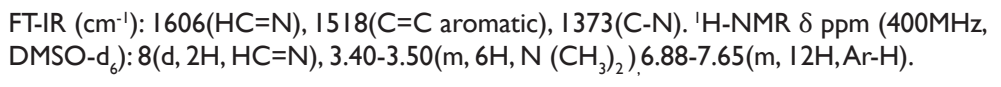 \\
\hline SW4 & 376.40 & 208 & 97 & $\begin{array}{l}\text { FT-IR }\left(\mathrm{cm}^{-1}\right): 3060(\mathrm{OH}), \mathrm{I} 6 \mathrm{II}(\mathrm{HC}=\mathrm{N}), \mathrm{I} 580(\mathrm{C}=\mathrm{C} \text { aromatic), I } 362(\mathrm{C}-\mathrm{N}) . \text { ' } \mathrm{H}-\mathrm{NMR} \delta \\
\text { PPm }\left(400 \mathrm{MHz}, \mathrm{DMSO}-\mathrm{d}_{6}\right): \mathrm{I} 6.40(\mathrm{~s}, 2 \mathrm{H}, \mathrm{OH}), 8.88(\mathrm{~s}, 2 \mathrm{H}, \mathrm{CH}=\mathrm{N}), 7.45-6.75(\mathrm{~m}, \mathrm{I} 2 \mathrm{H}, \mathrm{C}-\mathrm{H} \\
\text { aromatic). }\end{array}$ \\
\hline SW5 & 378.38 & 234 & 96 & $\begin{array}{l}\text { FT-IR }\left(\mathrm{cm}^{-1}\right): \text { I } 509(\mathrm{HC}=\mathrm{N}), I 509(\mathrm{C}=\mathrm{C} \text { aromatic }), \mathrm{I} 340(\mathrm{C}-\mathrm{N}), \mathrm{I} I 87(\mathrm{~N}=\mathrm{O}) . \text { 'H-NMR } \delta \\
\text { Ppm }\left(400 \mathrm{MHz}, \mathrm{DMSO}-\mathrm{d}_{6}\right): 8.73(\mathrm{~s}, 2 \mathrm{H}, \mathrm{CH}=\mathrm{N}), 8.4-7.4(\mathrm{~m}, \mathrm{I} 2 \mathrm{H}, \mathrm{C}-\mathrm{H} \text { aromatic }) .\end{array}$ \\
\hline SW6 & 408.49 & 217 & 85 & $\begin{array}{l}\text { FT-IR }\left(\mathrm{cm}^{-1}\right): \text { I } 590(\mathrm{HC}=\mathrm{N}), \mathrm{I} 529(\mathrm{C}=\mathrm{C} \text { aromatic }), \mathrm{I} 343(\mathrm{C}-\mathrm{N}) .{ }^{\prime} \mathrm{H}-\mathrm{NMR} \delta \mathrm{ppm}(400 \mathrm{MHz} \text {, } \\
\left.\text { DMSO-d }{ }_{6}\right): 5.42(\mathrm{~s}, 2 \mathrm{H}, \mathrm{CH}=\mathrm{N}), 7.70-6.36(\mathrm{~m}, \mathrm{IOH}, \mathrm{C}-\mathrm{H} \text { aromatic }), 3.8-4(\mathrm{~m}, \mathrm{IOH}, \\
\left.\mathrm{OC}_{2} \mathrm{H}_{5}\right) .\end{array}$ \\
\hline SW7 & 444.52 & 226 & 88 & $\begin{array}{l}\text { FT-IR }\left(\mathrm{cm}^{-1}\right): 3358(\mathrm{OH}), 1617(\mathrm{HC}=\mathrm{N}), 1569(\mathrm{C}=\mathrm{C} \text { aromatic), I I I } 7(\mathrm{C}-\mathrm{N}) \text {. ' } \mathrm{H}-\mathrm{NMR} \delta \mathrm{ppm} \\
\left(400 \mathrm{MHz}, \mathrm{DMSO}-\mathrm{d}_{6}\right): 9.7(\mathrm{~s}, 2 \mathrm{H}, \mathrm{CH}=\mathrm{N}), 8.6-7.05(\mathrm{~m}, \mathrm{I} \mathrm{H}, \mathrm{C}-\mathrm{H} \text { aromatic), I5(S, } 2 \mathrm{H}, \mathrm{OH}) .\end{array}$ \\
\hline
\end{tabular}

\section{Biology}

The entire synthesized compounds were screened for antimicrobial activity at a concentration $5 \mu \mathrm{M}$ against one Gram (-) strain (Escherichia coli), one Gram (+) bacterial strain (staphylococcus aureus) and one strain of fungi which is (candida albican) by agar diffusion methods. The results obtained from the antimicrobial activity studies of the synthesized Schiff's bases, propose that a few of them have a good activity against the studied microbes. The compound Sw4 showed excellent activity against $C$. albican compared to ketoconazole, while compound Sw3 exhibits moderate activity against $C$.albican (Table $3)$. In addition compound Sw4 was the only active in the series and was active against $S$. aureus and $E$. coli in addition to the significant activity on $\boldsymbol{C}$.albican (Table 3 ). The compound $\boldsymbol{S W} \mathbf{3}$ had a significant activity against Candida $(15 \mathrm{~mm})$ when compared to its activity on bacterial strains irrespectively to its Gram stain. The activity was due to dimethyl amine moiety at position para to the aldehyde indicates evidence of selectivity of the ligand to the target in Candida.

The Sw4 structure-activity relationship potency against $S$. aureus, E. coli and C. albicans could depend to a large extent on their ability to interact with thiol and hydroxyl of the benzene. ${ }^{19}$ Furthermore, the location of the hydroxyl group is powerfully involved, the orthoposition and not the para- or the meta-being the most constructive, because of a mechanism by which the $o$-hydroxyl groups are concerned in intermolecular hydrogen bond configuration assisting the addition of thiols and these results are consistent with the literature where Dinkova et al. ${ }^{20}$ found these ortho-hydroxyl groups exhibit a tendency for huge intermolecular hydrogen bond formation, which may elevate the reactivity and help addition of mercaptans, thus 
increasing inducer potencies. Finally, further study should be done on the mode of action of these compounds to explicate the structure to function correlation. According to different studies published on some Schiff base compounds, it was suggested that the mode of action may engage a variety of targets in microorganisms. ${ }^{21-23}$ These mechanisms could be classified into four points:

a. Inhibition of various cellular enzymes which are significant in the microorganism's metabolic pathway

b. The intrusion with the cell wall synthesis as a result the cell permeability which may be changed or they may muddle the lipoproteins leading to cell deaths, c. Destroying of one or more proteins of the cell, as a result of which the normal cellular processes are harmed.

d. Configuration of a hydrogen bond through the azomethine group with the active centres of cell components resulting in a conflict with the ordinary cell processes.

Due to the relationship in chemical structures with the previously studied compounds by many groups we could hypothesize that one of the earlier suggested targets could be well thought-out for our compounds. But our postulation should be proved by additional biochemical studies in the future.

Table 3 Zone of inhibition $(\mathrm{mm})$ and the MIC between brackets $(\mu \mathrm{g} / \mathrm{ml})$ data of the synthesized compounds

\begin{tabular}{|c|c|c|c|}
\hline \multirow{2}{*}{ Compounds } & \multicolumn{2}{|c|}{ Antibacterial activity } & \multirow{2}{*}{$\begin{array}{l}\text { Antifungal activity } \\
\text { C. albicans }\end{array}$} \\
\hline & S. aureus ${ }^{a}$ & E. coli ${ }^{a}$ & \\
\hline SWI & - & - & - \\
\hline SW2 & - & - & - \\
\hline SW3 & - & - & $15 \pm 0.96(0.09)$ \\
\hline SW4 & $29 \pm 0.35(0.32)$ & $25 \pm 0.92(0.26)$ & $25 \pm 1.10(0.12)$ \\
\hline SW5 & - & - & - \\
\hline SW6 & - & - & - \\
\hline SW7 & - & - & - \\
\hline Ciprofloxacin & $27 \pm 0.32(0.30)$ & $33 \pm 0.46(0.28)$ & - \\
\hline ketoconazole & - & - & $23 \pm 0.82(0.13)$ \\
\hline
\end{tabular}

The dash (-) indicates an absence of activity, ${ }^{a}$ Zone of inhibition $(\mathrm{mm})$ data are presented as mean values \pm standard deviation calculated from triplicate determinations. MIC values are given in brackets $(\mu \mathrm{g} / \mathrm{mL})$. Minimum inhibitory concentration, i.e. the lowest concentration of drug which completely inhibit bacterial growth.

\section{Conclusion}

In conclusion, seven Schiff bases were synthesized by reacting phenylenediamine with different aromatic aldehyde derivatives. The structures of the synthesised compounds were confirmed by diverse spectroscopic methods. The synthesized compounds were also biologically evaluated and they were tested against bacteria: $S$. aureus, E. coli and fungi: $C$. albicans. Compound $\boldsymbol{S W} 4$ exhibited good growth inhibition activity against bacteria and Candida and it is promising to act as a possible antimicrobial agent. Results also exposed that compound $\boldsymbol{S W} 3$ showed moderate activity against Candida; additional structural alterations might lead to a competent anticandida agent which could be used as anticandida drugs, particularly if additional work established that cytotoxicity of the synthesized Schiff bases is less than Nystatin.

\section{Acknowledgements}

None.

\section{Conflict of interest}

The author declares that there is no conflict of interest.

\section{References}

1. Thies H, Schonenberger H, Bauer KH. Reactions of Schiff's bases. V. Transformation of benzylidene-arylamines with mixtures of magnesium and magnesium iodide. Arch Pharm Ber Dtsch Pharm Ges. 1958;291/63(11-12):620-627.

2. Puchtler H, Meloan SN, Brewton BR. On the history of basic fuchsin and aldehyde-Schiff reactions from 1862 to 1935 . Histochemistry. 1975;41(3):185-194. 
3. Piscopo E, Diurno MV, Cirino G, et al. Biological activity of 4-hydroxy5-formylbenzoic acid derivatives. II. Esters and Schiff bases with antimicrobial activity. Boll Soc Ital Biol Sper. 1984;60(3):501-507.

4. Lubec G, Leban J, Peyroux J, et al. Reduced collagenolytic activity of rat kidneys with steptozotocin diabetes. Nephron. 1982;30(4):357-360.

5. Rahman AH, Ismail EM. Synthesis of Schiff bases of benzofuran with potential biological activity. Arzneimittelforschung. 1976;26(5):756-759.

6. Lamie PF, Ali WAM, Bazgier V, et al. Novel N-substituted indole Schiff bases as dual inhibitors of cyclooxygenase-2 and 5-lipoxygenase enzymes: Synthesis, biological activities in vitro and docking study. Eur J Med Chem. 2016;123:803-813.

7. Meng XY, Liu JQ, Zhang XP, et al. Synthesis and biological activities of 2,4-diamino-5-fluoro-6-substituted benzylamino quinazolines. Yao Xue Хие Вао. 1994;29(4):261-267.

8. Rashid R, Anwar Z, Zafar M, et al. Chitosan-alginate immobilized lipase based catalytic constructs: Development, characterization and potential applications. Int J Biol Macromol. 2018;119:992-1001.

9. Lamie PF, Ali WAM, Bazgier V, et al. Novel N-substituted indole Schiff bases as dual inhibitors of cyclooxygenase-2 and 5-lipoxygenase enzymes: Synthesis, biological activities in vitro and docking study. Eur J Med Chem. 2016;123:803-813.

10. Elshaarawy RF, Janiak C. Toward new classes of potent antibiotics: synthesis and antimicrobial activity of novel metallosaldach-imidazolium salts. Eur J Med Chem. 2014;75:31-42.

11. Paul A, Anbu S, Sharma G, et al. Synthesis, DNA binding, cellular DNA lesion and cytotoxicity of a series of new benzimidazole-based Schiff base copper(II) complexes. Dalton Trans. 2015;44(46):19983-19996.

12. Sakthikumar K, Dhaveethu RJ, Rajadurai VS, et al. Density Functional Theory Molecular Modelling, DNA interactions, Antioxidant, Antimicrobial, Anticancer and Biothermodynamic Studies of Bioactive Water Soluble Mixed Ligand Complexes. J Biomol Struct Dyn 2018;27:1-55

13. Karthikeyan MS, Prasad DJ, Poojary B, et al. Synthesis and biological activity of Schiff and Mannich bases bearing 2,4-dichloro-5-fluorophenyl moiety. Bioorg Med Chem. 2006;14(22):7482-7489.
14. Anush SM, Vishalakshi B, Kalluraya B, et al. Synthesis of pyrazolebased Schiff bases of Chitosan: Evaluation of antimicrobial activity. Int $J$ Biol Macromol. 2018;119:446-452.

15. Dhayabaran VV, Prakash TD. Synthesis and multi-spectroscopic study on DNA-binding, cleavage and biological properties of M(II) complexes based on N2 O2 donor Schiff base ligand. Luminescence. 2017;32(7):1339-1348

16. Diaz-Ortiz A, Prieto P, de la HA. A Critical Overview on the Effect of Microwave Irradiation in Organic Synthesis. Chem Rec; 2018

17. Berrino E, Supuran CT. Advances in microwave-assisted synthesis and the impact of novel drug discovery. Expert Opin Drug Discov. 2018;13(9):861-873.

18. Balouiri M, Sadiki M, Ibnsouda SK. Methods for in vitro evaluating antimicrobial activity: A review. J Pharm Anal. 2016;6(2):71-79.

19. Batovska D, Parushev S, Slavova A, et al. Study on the substituents' effects of a series of synthetic chalcones against the yeast Candida albicans. Eur J Med Chem. 2007;42(1):87-92.

20. Dinkova-Kostova AT, Massiah MA, Bozak RE, et al. Potency of Michael reaction acceptors as inducers of enzymes that protect against carcinogenesis depends on their reactivity with sulfhydryl groups. Proc Natl Acad Sci U S A. 2001;98(6):3404-3409.

21. Taghizadeh L, Montazerozohori M, Masoudiasl A, et al. New tetrahedral zinc halide Schiff base complexes: Synthesis, crystal structure, theoretical, 3D Hirshfeld surface analyses, antimicrobial and thermal studies. Mater Sci Eng C Mater Biol Appl. 2017;77:229-244.

22. Abdel-Rahman LH, Abu-Dief AM, El Khatib RM, et al. Some new nano-sized $\mathrm{Fe}(\mathrm{II}), \mathrm{Cd}(\mathrm{II})$ and $\mathrm{Zn}(\mathrm{II})$ Schiff base complexes as precursor for metal oxides: Sonochemical synthesis, characterization, DNA interaction, in vitro antimicrobial and anticancer activities. Bioorg Chem. 2016;69:140-152.

23. Abou-Hussein AA, Linert W. Synthesis, spectroscopic studies and inhibitory activity against bacteria and fungi of acyclic and macrocyclic transition metal complexes containing a triamine coumarine Schiff base ligand. Spectrochim Acta A Mol Biomol Spectrosc. 2015;141:223-232. 